\title{
Disciplinary Character Education of Cadets In Merchant Marine Polytechnic (PIP) Makassar
}

\author{
Rosnani \\ Merchant Marine Polytechnic (PIP) Makassar \\ Nautica Study Program, Merchant Marine Polytechnic (PIP) Makassar \\ Tentara Pelajar Street No.173, city of Makassar. South Sulawesi, Indonesia \\ rosnanizinichi@gmail.com
}

\begin{abstract}
Character education is about educating for character. In other words, it is leveraging education to encourage the development of character for students, and other stakeholders, in the educational context (Murray et al., 2019). This study aims to investigate the implementation of the disciplinary character education of cadets regarding time discipline, to obey the rules, discipline of behavior and worship in PIP Makassar. This research used qualitative descriptive research method. Techniques of data collection were observation, interviews and questionnaires. Population was cadets in the first Semester, second semester, fourth Semester and eighth semester cadets Diploma IV or Bachelor, deck, engine and port shipping management in PIP Makassar. A total population was 1291 respondents (cadets). The number of samples was 130 respondents (cadets) through stratified random sampling technique that is simple random sampling. The implementation of disciplinary character education in PIP Makassar had been running well based on the pattern of cadets parenting and set in the rules of order cadets, the cadets discipline levels were good category based on the results of questionnaire data, it was just supervision still needed to be improved and used the pattern or the method of positive habituation regarding discipline and obedience to the rules, because building disciplinary character education for cadets was hard, it needed an extra process starting from the educational institutions environment by implementing a quality system and positive environment based on the term of characters education. To inhibit undisciplinary had to implement academic sanctions or punishment that deterrent cadets who often made mistakes or acts of disciplinary violations repeatedly so that they can teach lessons for cadets who violate and other cadets who did not violate disciplinary actions.
\end{abstract}

Keywords: character education, discipline, cadets

\begin{abstract}
Abstrak. Pendidikan karakter adalah tentang mendidik karakter. Dengan kata lain, memanfaatkan pendidikan untuk mendorong pengembangan karakter bagi siswa, dan pemangku kepentingan lainnya, dalam konteks pendidikan (Murray et al., 2019). Penelitian ini bertujuan untuk mengetahui implementasi pendidikan karakter disiplin taruna tentang disiplin waktu, untuk mematuhi aturan, disiplin perilaku dan ibadah di PIP Makassar. Penelitian ini menggunakan metode penelitian deskriptif kualitatif. Teknik pengumpulan data adalah observasi, wawancara dan kuesioner. Populasi adalah kadet di semester pertama, semester kedua, semester keempat dan semester delapan Diploma IV atau Sarjana, Prodi Dek, Mesin dan Manajemen di PIP Makassar. Total populasi adalah 1.291 responden (taruna/i). Jumlah sampel adalah 130 responden (taruna/i) melalui teknik stratified random sampling yaitu simple random sampling. Implementasi pendidikan karakter kedisiplinan di PIP Makassar telah berjalan dengan baik berdasarkan pola pengasuhan taruna dan ditetapkan dalam aturan taruna/i, tingkat kedisiplinan taruna/i adalah kategori baik berdasarkan hasil data kuesioner, hanya saja pengawasan masih diperlukan untuk ditingkatkan dan menggunakan pola atau metode habituasi positif mengenai disiplin dan kepatuhan terhadap aturan, karena membangun pendidikan karakter disiplin untuk taruna/i sulit, diperlukan proses ekstra mulai dari lingkungan lembaga pendidikan dengan menerapkan sistem kualitas dan lingkungan positif berdasarkan istilah karakter pendidikan. Untuk menghambat ketidakdisiplinan harus menerapkan sanksi atau hukuman akademik yang menghalangi taruna/i yang sering melakukan kesalahan atau tindakan pelanggaran disipliner berulang kali sehingga mereka dapat mengajarkan taruna/i yang melanggar dan taruna/i lainnya yang tidak melanggar tindakan disipliner.
\end{abstract}

Kata Kunci: Pendidikan karakter, disiplin, taruna/i 


\section{INTRODUCTION}

Education is a process in which the nation organizes young generation to run a life, and achieve life's goals effectively and efficiently. Education is one of the normative efforts that represents the better values, which are part of the life of the nation and later these values can be continued through the role of the transfer of education among cognitive, affective and psychomotor aspects. According to Djamarah in Astriani Wangka \& Mustahidang U. (2017:69 as cited in Sujarwo; Sukmawati;Yahrif, 2019) stated that education is conscious effort and aims to develop quality. Character building of the nation of generation is the aim of National Education, as referred to in RI Law No. 20 of 2003, stated that the functions and objectives of national education are as follows: National education functions to develop competencies and shapes the character and civilization of a dignified nation in order to educate the life of the nation, the aim to develop the potential of students to become human beings who believe in and fear God Who Almighty, noble, healthy, knowledgeable, capable, creative, independent, and become citizens of a democratic and responsible. Education has to be carried out continuously so that the change of thinking way, attitude and behavior occurs; finally it establishes the uniting characters appropriate to the education goal itself (Irawatie et al., 2019).
Character education has a crucial role to overcome the crisis of identity that is currently affecting Indonesian country, and various cases that have repeatedly surfaced and struck the people's trust and belief in their shared identity as Indonesian people. The Character Education offers the character education as the core in the implementation of education within the elementary school (Muttaqin \& Raharjo, 2018). Furthermore, The assumptions used by means of teachers or lecturers that all college students have extra or muchless the same trait s (Akhiruddin; Sujarwo, 2020).

So, the success of persona training in colleges and instructional institutions is to promote students' discipline. Self-discipline of students' goals to help to locate themselve, solve, and prevent the emergence of disciplinary problems, as nicely as trying to create an atmosphere that is safe, comfortable, and enjoyable for mastering activities, so they obey the rules applied. Character schooling in the us of a beginning from primary education, as in the United States, Japan, China, and Korea. Some evidences that the implementation of personality education are organized systematically without a doubt have a positive effect on tutorial fulfillment (Kamaruddin, 2012). And The developing attention of the significance of character training in higher training is now not accompanied by means of an ample amount of research on this particular subject matter (Novianti, 2017). 
PIP Makassar as one of institutions held in maritime field and produces graduates of Diploma IV or bachelor of sailing training program and given the authority to carry out the Seafarers Training Program and Seafarers Skill Training Program based on KM.No.46 of 2009. Disciplinary character education is done at PIP Makassar starting from candidate of cadets by following the first stage, namely the orientation / transition phase, they follow the character-building training during one month, ntensifying stage, and developing stage.

The process of implementation through the rules or regulations for cadets in daily activities with a good and true habituation method. The application of discipline character education begins the campus code of conduct or rules of cadets' discipline. The types of discipline are the implementation of morning ceremony every day, lunch ceremony, enter to class on time, return on cruise on time, come to campus on time at 6:00 P.M for cadets wreda or live outside the campus. When cadets do not follow or adhere the applicable rules / regulations, they will get points of mistake and theit parents will be called to campus and will be given sanctions based on violations of disciplinary action done.

Based on interviews with cadets instructors and one of the cadets company officers stated that cadets discipline were good but they still had lack discipline in the aspects of time discipline, attitude, obeying rules and worship, namely coming late to campus, smoking, leaving campus without asking permission and did not enter class when the class was teaching and learning process, and did not do the prayer in congregation (jama'h).

Based on data, the conditions and violations of cadets in 2015 - 2017, cadets character development center (PPKT) in 2015 there were 69 cadets who could not complete their education process because of the violations of cadets, discipline and cadets were sick. There were 31 cadets who could not participate the education process and activities of cadets and two cadets who resigned in 2016 while there were 26 cadets who could not participate cadets' activities and four cadets were dismissed respect in 2017 (January July). Based on data below:

\begin{tabular}{|l|l|c|c|c|}
\hline & \multicolumn{2}{|c|}{$\begin{array}{l}\text { Cadets' } \\
\text { No }\end{array}$} & \multicolumn{3}{|c|}{ Year } \\
\cline { 2 - 5 } 1 & $\begin{array}{l}\text { Drop Ondition } \\
\text { /DO }\end{array}$ & 2015 & 2016 & 2017 \\
\hline 2 & Punishment & 48 & 21 & 4 \\
\hline 3 & $\begin{array}{l}\text { Academic } \\
\text { leave }\end{array}$ & 12 & 7 & 1 \\
\hline \multicolumn{2}{|l|}{ Total } & 69 & 31 & 26 \\
\hline
\end{tabular}

Table .1.1 (source: PKT)

While data of the cadets' attendance and violation from 2016 - July 2017, the level of absence from campus reached an average of $10 \%$ - 12\%/month, generally in second semester, third and fourth semester also the late payment of meal costs for cadets, it is clearly illustrated that the discipline of cadets related to the discipline character eas still lack.

Based on that situation, the researchers are interested in conducting this research on 
how does the disciplinary character education of cadets implement the discipline and daily activities in PIP Makassar?

\section{Character Education}

According to some experts, the word of education has different definitions, it depends on the viewpoints, paradigms, methodologies and scientific disciplines used such as: According to D. Rimba, education is "Guidance or conscious by educators of the physical and spiritual development of students towards the formation of a whole personality. Then, Education is not a separate thing from human life and it is also a key to the success development. The quality of human resource is a basic element in the competence of globalization era (Limbong, 2018). So that, character education is a growing discipline with the deliberate attempt to optimize students' ethical behavior (Berkowitz \& Hoppe, 2009; Katilmis, Eksi, \& Öztürk, 2011 as cited in (Tsai, 2012). Referring to the various understandings and definitions of education and character can simply be interpreted that character education is a conscious effort by a person or group of people (educators) to internalize character values to the learners as enlightenment so that they know, think and act morally in the face of every situation. Many experts express their opinions on character education, including Lickona who defines character education as a genuine effort to help someone understand, care and act on the basis of ethical values. The process of character education consists of operative score, which is a value that affects individuals (Sri Rahayuningsih1, 2016). And Good character is not formed automatically; it is developed over time through a sustained process of teaching, example, learning and practice (Adams, 2011).

\section{The Purpose of Character Education}

Basically, character education aims to improve the quality of implementation and educational outcomes that lead to the achievement of character building or noble character of students in full, integrated, and balanced, in accordance with the competency standards of graduates. Through character education students are expected to be able to independently improve and use their knowledge, study and internalize and personalize the values of character and noble character so that it is manifested in daily behavior. According to the Ministry of National Education (2010: 26) indicators of the discipline value are as follows: (a) used to being on time. (b) used to obey the rules. (c) wearing clothes and attributes in based on the provisions.

This was also stated by Jamal Ma'mur (2013: 94) that the dimensions of discipline are (a) Discipline of time, (b) Discipline to enforce rules, (c) Discipline of attitude, (d) Discipline of worship ". 


\section{Guidance of Cadets Parenting Pattern}

Guidance of cadets parenting pattern was arranged with the aims of obtaining the same actions in implementing cadets parenting pattern training at UPT within BPSDM Transportation in educational and training institution within the Transportation Human Resources Development Agency.

The purpose of Parenting Pattern of cadets is to make more effectively and efficiency the achievement of educational and training objectives that the implementation is to optimize the ability of cadets Building Training in UPT in BPSDM Transportation in developing aspects of the attitudes, behaviors of knowledge and skills also physical during participating Education and Training.

\section{Cadets Rules of Procedure (PERTIBTAR)}

The Cadets Rules of Procedure based on Decree Director of PIP Makassar Number: sm. 002 /sk.b.2030 / ix / pip mks-2015 Date: 30 September 2015 applies to PIP Makassar Cadets since the Candidates is declared as cadets until graduation or until the time concerned is not declared as a cadest.

\section{RESEARCH METHODS}

This study applied a qualiitative descriptive research method which is adapted from that descriptive qualitative research is exploring and understanding of individual or group thinking ascribe to social or human problem (Creswell, 2009) which systematically described the application of discipline character education of cadets in PIP Makassar. The research was conducted at PIP Makassar with the object of research namely the first semester cadets, second semester cadets, fourth semester cadets and eighth semester cadets Diploma IV or Bachelor Shipping Program of PIP Makassar.

To collect data that supporting this study, researchers used several techniques, namely: observation, questionnaires and interviews. The population in this study was cadets in the first semester, second semester, fourth semester and eighth semester in Deck, Engine, Port Shipping Managemen programs or PIP Makassar. The total population of this study was 1291 cadets. The number of samples in this study was 130 cadets. The sample size was taken based on explanation of (Sugiyono, 2018) which stated that if the subjects were more than 100 , the samples taken were around $10-20 \%$ or more than the total population. The sampling technique used stratified random sampling, which was taking simple random sampling.

\begin{tabular}{|c|c|c|c|c|c|}
\hline \multirow[b]{2}{*}{ No } & \multirow[b]{2}{*}{$\begin{array}{c}\text { Seme } \\
\text { ster }\end{array}$} & \multicolumn{3}{|c|}{ Majors } & \multirow[b]{2}{*}{$\begin{array}{c}\text { Numb } \\
\text { ers }\end{array}$} \\
\hline & & $\begin{array}{l}\mathrm{D} \\
\mathrm{ec} \\
\mathrm{k}\end{array}$ & $\begin{array}{l}\text { Engi } \\
\text { ne }\end{array}$ & $\begin{array}{c}\text { Port } \\
\text { Shipping } \\
\text { Manage } \\
\text { men }\end{array}$ & \\
\hline 1 & VIII & 5 & 5 & 5 & 15 \\
\hline 2 & IV & 20 & 20 & 10 & 50 \\
\hline 3 & II & 20 & 20 & 10 & 50 \\
\hline 4 & I & 5 & 5 & 5 & 15 \\
\hline \multicolumn{2}{|c|}{ Total } & 50 & 50 & 30 & 130 \\
\hline
\end{tabular}

Data Processing Techniques

Data Processing Techniques used was to collect all data both from observation and interview, reducing data, presenting data and 
verifying data. Data obtained from the questionnaire were arranged a list or table and percentage analysis was performed using a Likert scale.

$$
P=\frac{F}{N} \times 100 \%
$$

Where: P: Percentage F: Frequency of Respondents' Answers N: Number of Respondents.

\section{Data Analysis Techniques}

Analysis of data used was descriptive analysis. This analysis was used to describe systematically, factually and accurately about the facts obtained. The data obtained presented through frequency tables that analyzed by percentage. As a criterion for the interpretation of percentage values. Respondents' answers are as follows:

$$
\begin{aligned}
& 0-25 \%=\text { Very Poor } \\
& 26 \%-50 \%=\text { Poor } \\
& 51 \%-75 \%=\text { Fair } \\
& 76 \%-100 \%=\text { Good }
\end{aligned}
$$

Data obtained from interviews were used as a complement in narrative description to explain the research findings.

\section{DISCUSSION}

The research results of discipline character education of cadets in PIP Makassar that based on questionnaires and interviews research instruments distributed to the sample in Dect, Engine cadets, and Port Shipping Managemen Programs.
The Results of Research based on

\section{Questionnaires}

In general, research instruments used were interviews and questionnaires, to find out how the implementation of discipline character education in cadets of time discipline, discipline obeying regulations, attitude discipline and worship discipline. From the fourth dimensions of discipline character applied into positive and negative statements related to the level of discipline of cadets in implementing the character education of cadets in PIP Makassar as recapitulation results follow:

\begin{tabular}{|c|c|c|c|c|c|c|c|c|}
\hline & $\begin{array}{l}\mathrm{N} \\
\mathrm{o}\end{array}$ & Statement & $\begin{array}{l}\mathrm{S} \\
\mathrm{L}\end{array}$ & $\begin{array}{l}\mathrm{S} \\
\mathrm{R}\end{array}$ & $\mathbf{J}$ & $\begin{array}{l}\mathbf{J} \\
\mathrm{S}\end{array}$ & $\begin{array}{l}\mathrm{T} \\
\mathrm{P}\end{array}$ & $\begin{array}{c}\text { Score } \\
\text { Category } \\
\text { percenta } \\
\text { ge }\end{array}$ \\
\hline \multirow{4}{*}{ I } & 1 & $\begin{array}{l}\text { Coming } \\
\text { home on } \\
\text { time }\end{array}$ & $\begin{array}{l}92 \\
70 \\
\%\end{array}$ & $\begin{array}{l}14 \\
11 \\
\%\end{array}$ & $\begin{array}{l}24 \\
19 \\
\%\end{array}$ & & & Fair \\
\hline & $\begin{array}{l}2 \\
.\end{array}$ & $\begin{array}{l}\text { Entering } \\
\text { class on } \\
\text { time }\end{array}$ & $\begin{array}{l}74 \\
57 \\
\% \\
\end{array}$ & $\begin{array}{l}19 \\
14 \\
\% \\
\end{array}$ & $\begin{array}{l}33 \\
26 \\
\%\end{array}$ & $\begin{array}{l}4 \\
3 \\
\% \\
\end{array}$ & & Fair \\
\hline & $\begin{array}{l}3 \\
.\end{array}$ & $\begin{array}{l}\text { Doing } \\
\text { assignmen } \\
t \text { from } \\
\text { lecturer on } \\
\text { time }\end{array}$ & $\begin{array}{l}10 \\
4 \\
80 \\
\%\end{array}$ & $\begin{array}{l}7 \\
6 \\
\%\end{array}$ & $\begin{array}{l}19 \\
14 \\
\%\end{array}$ & & & Good \\
\hline & 4 & $\begin{array}{l}\text { Paying } \\
\text { meal } \\
\text { allowance } \\
\text { on time }\end{array}$ & $\begin{array}{l}30 \\
23 \\
\%\end{array}$ & $\begin{array}{l}41 \\
31 \\
\%\end{array}$ & $\begin{array}{l}28 \\
22 \\
\%\end{array}$ & $\begin{array}{l}8 \\
6 \\
\%\end{array}$ & $\begin{array}{l}2 \\
1 \\
1 \\
8 \\
\%\end{array}$ & Lack \\
\hline & 5 & $\begin{array}{l}\text { Wearing } \\
\text { complete } \\
\text { uniform }\end{array}$ & $\begin{array}{l}10 \\
1 \\
78 \\
\%\end{array}$ & $\begin{array}{l}8 \\
7 \\
\%\end{array}$ & $\begin{array}{l}14 \\
11 \\
\%\end{array}$ & $\begin{array}{l}5 \\
4 \\
\%\end{array}$ & & Good \\
\hline
\end{tabular}

\section{Recapitulation of the discipline levels} related to positive statements of respondents (Cadets)

A. Positive Statement 


\begin{tabular}{|c|c|c|c|c|c|c|c|}
\hline & $\begin{array}{l}6 \\
.\end{array}$ & $\begin{array}{l}\text { Attending } \\
\text { flag } \\
\text { ceremony }\end{array}$ & $\begin{array}{l}11 \\
4 \\
88 \\
\%\end{array}$ & $\begin{array}{l}11 \\
8 \\
\%\end{array}$ & $\begin{array}{l}5 \\
4 \\
\%\end{array}$ & & Good \\
\hline & 7 & $\begin{array}{l}\text { Attending } \\
\text { morning } \\
\text { ceremony }\end{array}$ & $\begin{array}{l}10 \\
3 \\
79 \\
\%\end{array}$ & $\begin{array}{l}21 \\
16 \\
\%\end{array}$ & $\begin{array}{l}6 \\
5 \\
\%\end{array}$ & & Good \\
\hline $\begin{array}{l}\text { I } \\
\text { I }\end{array}$ & 8 & $\begin{array}{l}\text { Attending } \\
\text { day } \\
\text { ceremony } \\
\text { while } \\
\text { preparatio } \\
\text { n of } \\
\text { having } \\
\text { lunch } \\
\end{array}$ & $\begin{array}{l}11 \\
2 \\
86 \\
\%\end{array}$ & $\begin{array}{l}10 \\
8 \\
\%\end{array}$ & $\begin{array}{l}8 \\
6 \\
\%\end{array}$ & & Good \\
\hline & 9 & $\begin{array}{l}\text { Attending } \\
\text { evening } \\
\text { ceremony }\end{array}$ & $\begin{array}{l}10 \\
1 \\
78 \\
\%\end{array}$ & $\begin{array}{l}18 \\
14 \\
\%\end{array}$ & $\begin{array}{l}11 \\
8 \\
\%\end{array}$ & & Good \\
\hline & $\begin{array}{l}1 \\
0\end{array}$ & $\begin{array}{l}\text { Following } \\
\text { have } \\
\text { breakfast }\end{array}$ & $\begin{array}{l}11 \\
7 \\
90 \\
\% \\
\end{array}$ & $\begin{array}{l}13 \\
10 \\
\%\end{array}$ & & & Good \\
\hline & $\begin{array}{l}1 \\
1\end{array}$ & $\begin{array}{l}\text { Following } \\
\text { have } \\
\text { lunch }\end{array}$ & $\begin{array}{l}12 \\
8 \\
98 \\
\%\end{array}$ & $\begin{array}{l}2 \\
2 \\
\%\end{array}$ & & & Good \\
\hline & $\begin{array}{l}1 \\
2\end{array}$ & $\begin{array}{l}\begin{array}{l}\text { Following } \\
\text { have } \\
\text { dinner }\end{array} \\
\end{array}$ & $\begin{array}{l}12 \\
6 \\
97 \\
\end{array}$ & $\begin{array}{l}4 \\
3 \\
\% \\
\end{array}$ & & & Good \\
\hline & $\begin{array}{l}1 \\
3\end{array}$ & \begin{tabular}{|l} 
Giving \\
informatio \\
$\mathrm{n}$ when \\
absent \\
\end{tabular} & $\begin{array}{l}10 \\
5 \\
81 \\
\% \\
\end{array}$ & $\begin{array}{l}4 \\
3 \\
\%\end{array}$ & $\begin{array}{l}18 \\
14 \\
\%\end{array}$ & $\begin{array}{l}3 \\
2 \\
\%\end{array}$ & Good \\
\hline & $\begin{array}{l}1 \\
4\end{array}$ & \begin{tabular}{|l|} 
Giving \\
permissio \\
nn based \\
on \\
procedure \\
when goig \\
outside \\
\end{tabular} & $\begin{array}{l}89 \\
69 \\
\%\end{array}$ & $\begin{array}{l}12 \\
9 \\
\%\end{array}$ & $\begin{array}{l}29 \\
22 \\
\%\end{array}$ & & Fair \\
\hline & $\begin{array}{l}1 \\
5\end{array}$ & \begin{tabular}{|l|} 
Doing \\
guard \\
duties \\
responsibi \\
lity \\
\end{tabular} & $\begin{array}{l}12 \\
6 \\
97 \\
\%\end{array}$ & $\begin{array}{l}4 \\
3 \\
\%\end{array}$ & & & Good \\
\hline I & $\begin{array}{l}1 \\
6\end{array}$ & $\begin{array}{l}\text { Throwing } \\
\text { rubbish on } \\
\text { the place }\end{array}$ & $\begin{array}{l}88 \\
68 \\
\%\end{array}$ & $\begin{array}{l}17 \\
13 \\
\%\end{array}$ & $\begin{array}{l}11 \\
9 \\
\%\end{array}$ & $\begin{array}{l}1 \\
4 \\
1 \\
0 \\
\% \\
\end{array}$ & Fair \\
\hline $\begin{array}{l}\text { I } \\
\text { I }\end{array}$ & $\begin{array}{l}1 \\
7\end{array}$ & \begin{tabular}{|l|} 
Talking \\
polite on \\
governme \\
nt board \\
and all \\
staffs \\
\end{tabular} & $\begin{array}{l}10 \\
2 \\
78 \\
\%\end{array}$ & $\begin{array}{l}28 \\
22 \\
\%\end{array}$ & & & Good \\
\hline & $\begin{array}{l}1 \\
8\end{array}$ & $\begin{array}{l}\text { Being } \\
\text { polite and }\end{array}$ & $\begin{array}{l}11 \\
7\end{array}$ & $\begin{array}{l}13 \\
10 \\
\%\end{array}$ & & & Good \\
\hline
\end{tabular}

\begin{tabular}{|c|c|c|c|c|c|c|}
\hline & & $\begin{array}{l}\text { respect } \\
\text { with peer }\end{array}$ & $\begin{array}{l}90 \\
\%\end{array}$ & & & \\
\hline I & $\begin{array}{l}1 \\
9\end{array}$ & $\begin{array}{l}\text { Doing } \\
\text { prayers in } \\
\text { congregati } \\
\text { on }\end{array}$ & $\begin{array}{l}77 \\
60 \\
\%\end{array}$ & $\begin{array}{l}13 \\
10 \\
\%\end{array}$ & $\begin{array}{l}40 \\
30 \\
\%\end{array}$ & Fair \\
\hline V & $\begin{array}{l}2 \\
0\end{array}$ & $\begin{array}{l}\text { Doing } \\
\text { Jumat } \\
\text { prayer for } \\
\text { moslim } \\
\text { and } \\
\text { worship } \\
\text { for non } \\
\text { muslim }\end{array}$ & $\begin{array}{l}10 \\
9 \\
84 \\
\%\end{array}$ & $\begin{array}{l}15 \\
12 \\
\%\end{array}$ & $\begin{array}{l}6 \\
4 \\
\%\end{array}$ & Good \\
\hline
\end{tabular}

Table 4.1 The Results of data 2017

Criteria for interpretation of the percentage value seen from the choice that always or often Respondents' answers chosen were the highest percentage values in each items of statement. Respondents' answers were as follows:

$$
\begin{aligned}
& 0-25 \%=\text { No good } \\
& 26 \%-50 \%=\text { Lack } \\
& 51 \%-75 \%=\text { Fair } \\
& 76 \%-100 \%=\text { Good }
\end{aligned}
$$

From the recapitulation of cadets' disciplinary levels related to positive statements, there were 20 positive statement items which included time discipline, regulatory discipline, behavioral discipline and worship discipline. There were 14 items of respondents' answers that included both good and fair categories of 4 and less 1 category. There were 130 respondents as samples, most of the answers in each positive statement answered always or often. So all of them understood what was said by the rules and discipline with the good category but there were still having lack discipline related to time discipline such as paying food allowance each month based on the results of the questionnaire 
data from 130 respondents only 30 respondents or around 23\% who answered always pay for meals on time and they answered often around 41 respondents. Or about $31 \%$, when added up to 71 respondents who answered always and often from a total sample of 130 respondents. Whereas time disciplines were fair category such as returning home on time, getting to class on time, and there was still fair category related to discipline to obey the rules such as permits based on procedures when you wanted to leave campus and disposed of trash in its place. For the discipline of worship, there was also still fair category with a percentage of $66 \%$ or around 77 respondents who answered to worship in congregation.

\section{Recapitulation of the discipline levels} related to Negative statements of respondents (Cadets)

B. Negative statements (-)

\begin{tabular}{|c|c|c|c|c|c|c|c|c|}
\hline & $\begin{array}{l}\mathrm{N} \\
\mathrm{o}\end{array}$ & Statement & $\begin{array}{l}\text { S } \\
\mathrm{L}\end{array}$ & $\begin{array}{l}\mathrm{S} \\
\mathrm{R}\end{array}$ & $\mathrm{J}$ & $\begin{array}{l}J \\
S\end{array}$ & $\begin{array}{l}\mathrm{T} \\
\mathrm{P}\end{array}$ & $\begin{array}{c}\text { Score } \\
\text { Category } \\
\text { percenta } \\
\text { ge }\end{array}$ \\
\hline \multirow{4}{*}{ I } & 1 & $\begin{array}{l}\text { Coming } \\
\text { home on } \\
\text { time }\end{array}$ & $\begin{array}{l}92 \\
70 \\
\%\end{array}$ & $\begin{array}{l}14 \\
11 \\
\%\end{array}$ & $\begin{array}{l}24 \\
19 \\
\%\end{array}$ & & & Fair \\
\hline & $\begin{array}{l}2 \\
.\end{array}$ & $\begin{array}{l}\text { Entering } \\
\text { class on } \\
\text { time }\end{array}$ & $\begin{array}{l}74 \\
57 \\
\% \\
\end{array}$ & $\begin{array}{l}19 \\
14 \\
\%\end{array}$ & $\begin{array}{l}33 \\
26 \\
\%\end{array}$ & $\begin{array}{l}4 \\
3 \\
\%\end{array}$ & & Fair \\
\hline & 3 & $\begin{array}{l}\text { Doing } \\
\text { assignmen } \\
\mathrm{t} \text { from } \\
\text { lecturer on } \\
\text { time }\end{array}$ & $\begin{array}{l}10 \\
4 \\
80 \\
\%\end{array}$ & $\begin{array}{l}7 \\
6 \\
\%\end{array}$ & $\begin{array}{l}19 \\
14 \\
\%\end{array}$ & & & Good \\
\hline & 4 & $\begin{array}{l}\text { Paying } \\
\text { meal } \\
\text { allowance } \\
\text { on time }\end{array}$ & $\begin{array}{l}30 \\
23 \\
\%\end{array}$ & $\begin{array}{l}41 \\
31 \\
\%\end{array}$ & $\begin{array}{l}28 \\
22 \\
\%\end{array}$ & $\begin{array}{l}8 \\
6 \\
\%\end{array}$ & $\begin{array}{l}2 \\
1 \\
1 \\
8 \\
\%\end{array}$ & Lack \\
\hline
\end{tabular}

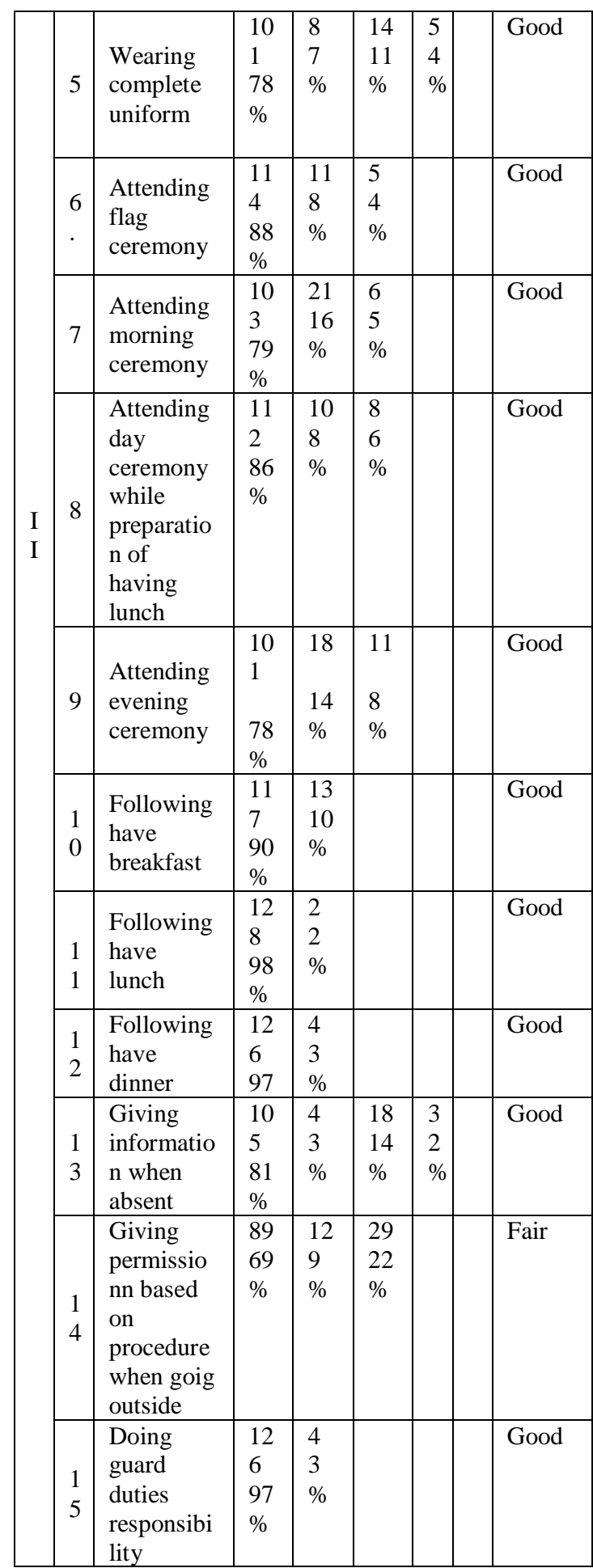

\begin{tabular}{|l|l|l|l|l|l|l|l|l|}
\hline & & & 88 & 17 & 11 & 1 & & Fair \\
& 1 & $\begin{array}{l}\text { Throwing } \\
\text { rubbish on } \\
\text { the place }\end{array}$ & 68 & 13 & 9 & 4 & & \\
I & 6 & & $\%$ & 1 & & \\
I & 1 & $\begin{array}{l}\text { Talking } \\
\text { polite on }\end{array}$ & 10 & 28 & & & & \\
I & 7 & & & & & & Good \\
\hline
\end{tabular}




\begin{tabular}{|c|c|c|c|c|c|c|}
\hline & & $\begin{array}{l}\text { governme } \\
\text { nt board } \\
\text { and all } \\
\text { staffs }\end{array}$ & $\begin{array}{l}78 \\
\%\end{array}$ & $\begin{array}{l}22 \\
\%\end{array}$ & & \\
\hline & $\begin{array}{l}1 \\
8\end{array}$ & $\begin{array}{l}\text { Being } \\
\text { polite and } \\
\text { respect } \\
\text { with peer }\end{array}$ & $\begin{array}{l}11 \\
7 \\
90 \\
\%\end{array}$ & $\begin{array}{l}13 \\
10 \\
\%\end{array}$ & & Good \\
\hline I & $\begin{array}{l}1 \\
9\end{array}$ & $\begin{array}{l}\text { Doing } \\
\text { prayers in } \\
\text { congregati } \\
\text { on } \\
\end{array}$ & $\begin{array}{l}77 \\
60 \\
\%\end{array}$ & $\begin{array}{l}13 \\
10 \\
\%\end{array}$ & $\begin{array}{l}40 \\
30 \\
\%\end{array}$ & Fair \\
\hline $\mathrm{V}$ & $\begin{array}{l}2 \\
0\end{array}$ & $\begin{array}{l}\text { Doing } \\
\text { Jumat } \\
\text { prayer for } \\
\text { moslim } \\
\text { and } \\
\text { worship } \\
\text { for non } \\
\text { muslim }\end{array}$ & $\begin{array}{l}10 \\
9 \\
84 \\
\%\end{array}$ & $\begin{array}{l}15 \\
12 \\
\%\end{array}$ & $\begin{array}{l}6 \\
4 \\
\%\end{array}$ & Good \\
\hline
\end{tabular}

Table 4.2 Results of data 2017

From the recapitulation of cadets' disciplinary level related to negative statements showed that there were 25 negative statement items in which there were types of violations regarding time discipline, regulations discipline, behavioral discipline and worship discipline. There were 15 types of disciplinary violations based on the results of data questionnaire for cadets' disciplinary levels still classified as good category, it meant that cadets violations levels of the four dimensions such as time discipline, discipline to obey the rules, discipline of behavior and discipline of worship.

From these four dimensions that still need to be improved in their implementation such as time discipline and discipline to obey regulations because the results of questionnaire data related to the cadets discipline levels, it was clearly seen that negative statements such as late paying food allowance, carrying and smoking cigarettes in the campus environment and the results of questionnaire data, there were still around $47 \%$ (61 cadets) who still commited such violations so that the results of the percentage of cadets were still discipline category of applicable regulations. the category of lack of statement or negative statement was cheating during exams, around 43 respondents who said they always cheated when the exam ran and around 37 respondents who answered often cheat during exams so that there were around 80 respondents/cadets always or often cheating during exams, this included cadets who did not obey the rules so that the cadets were the category of lack of discipline and must be improved by getting used to always doing good things based on applicable regulations and did not do good habituation such as cheating during exams.

Furthermore, based on the results of interviews with all cadets that the character education has been running well but it has not been maximized and still needed to be improved more, in this case based on assessment showed that the supervision levels were still lack including there were still instructors and employees who were not too care with the discipline of cadets was lack of attention or reprimand if someone commited an act of violation both the terms of actions and attitudes. According to them the supervision was still lack, so there were still some cadets who commited disciplinary violations and also who often perform disciplinary actions are 
senior cadets or transition cadets who think themselves as senior so they usually carried out the rules as they wished and used the luck only. Enforcement of discipline in the campus environment was not only related to issues surrounding attendance or not, being late or not. It refered to the environment in which there were respected shared rules, and anyone who violated might be responsible for their actions.

While the results of interviews with several instructors or govern board said that disciplinary character education in PIP Makassar has been running well it was just the need for good supervision and habituation given to cadets so that they can model good behavior and high discipline. Cadets will form a discipline of character and good behavior. Because character education will be formed if all elements involved in the education, work together with each other or be involved optimally. According to them said that the process of character formation and habituation is the responsibility of formal educational institutions after informal education in family environment.

\section{Discussion of the research results in the implementation of Discipline Character} Education of Cadets in PIP Makassar.

From the description above showed that from the four indicators of cadets discipline characters such as time discipline, discipline to obey the rules, behavioral discipline and worship discipline that there were 130 respondents as samples based on the results of questionnaire data showed that both positive statements and negative statements that categorized as fair and lack were average for the dimensions of time discipline, discipline to obey the rules and discipline of worship.

Because based on the results of interviews with cadets as samples stated that the implementation of disciplinary character education for cadets conducted by PIP Makassar has been going well and it is relevant with the research result conducted by Surabaya Shipping Polytechnic is very good and effective for Evaluation of character education (Putri et al., 2019) and it was just based on data no optimal and still needs to be improved more in this case according to their assessment, the level of supervision was still lack including there were instructors and employees who were not too concerned with the discipline of cadets in this case the lack of attention or reprimand if someone commited an act of violation both terms of actions and attitudes so that there were still some cadets who commited violations. According to them supervision must still be increased again and there should be sanctions that can create a deterrent effect for cadets who often make mistakes or disciplinary violations repeatedly so that they can provide lessons for other cadets did not violate disciplinary actions.

The lecturers or instructors not only responsible for the acquisition of students' 
knowledge but also instilled character in cadets' hearts and behavior. If the lecturer teaches manners, honesty and other positive values, then he must first be able to set an example in real behavior to be polite, honest and practice other positive values. There is no greater power than a lecturer without he/she makes himself/herself an example or role model. So it is available with a term that educates character by character.

\section{CONCLUSION}

Based on the results of research and the description that has been stated above, it can be concluded as follows: the implementation of disciplinary character education in PIP Makassar had been running well based on the pattern of cadets parenting and set in the rules of order cadets, the cadets discipline levels were good category based on the results of questionnaire data processing, it was just supervision still needs to be improved and use the pattern or the method of positive habituation regarding discipline and obedience to the rules, because building disciplinary character education for cadets was hard, it needed an extra process starting from the educational institutions environment by implementing a quality system and positive environment based on the term of characters education. To prevent undisciplinary has to implement academic sanctions or punishment that deterrent the cadets who often made mistakes or actsof disciplinary violations repeatedly so that they can teach lessons for cadets who violate and other cadets who did not violate disciplinary actions.

\section{REFERENCES}

[1] Adams, A. (2011). the Need for Character Education. International Journal of Social Sciences and Humanity Studies, 3(2), 23-32.

[2] Akhiruddin; Sujarwo. (2020). The Implementation Of Instructional Materials Development Based On Inside Outside Circle (IOC) For Students 'Sociology Education Of Megarezky University. 5(1), 86-94.

[3] Creswell, J. W. (2009). Research Design: Qualitatif, Quantitative, and Mixed Methods Approaches. Third Edition (Terjemahan) 2013 Research Design: Pendekatan Kualitatif, Kuantitatif, dan Mixed. (Third Edit). Yogyakarta: Pustaka Pelajar.

[4] Irawatie, A., Iswahyuni, I., \& Setyawati, M. E. (2019). Education Learning Development of Character Education-Based State Defense. International Journal of Multicultural and Multireligious Understanding, 6(2), 27-42. https://ijmmu.com/index.php/ijmmu/article/v iew/602

[5] Kamaruddin, S. A. (2012). Character Edcation and SsBehavior. Journal of Education and Learning, 6(4), 223-230. https://www.neliti.com/id/publications/72829 /character-education-and-students-socialbehavior

[6] Limbong, S. (2018). Competences Toward Students 'Writing Proficiency At. VENUS, 6(12), 57-72.

[7] Murray, E. D., Berkowitz, M. W., \& Lerner, R. M. (2019). Leading With and for Character: The Implications of Character Education Practices for Military Leadership. The Journal of Character \& Leadership Development, Winter, 32-42. https://jcli.scholasticahq.com/article/7520.pd f

[8] Muttaqin, M. F., \& Raharjo, T. J. (2018). The Implementation Main Values of Character Education Reinforcement in Elementary School. Journal of Primary Education, 7(1), 
103-112.

[9] Novianti, N. (2017). Teaching character education to college students using bildungsromans. International Journal of Instruction, 10(4), 255-272. https://doi.org/10.12973/iji.2017.10415a

[10] Putri, I. M., Roesminingsih, E., \& Wuryani, E. (2019). Management of Character Education in Realizing Cadets Who Ethically in Politeknik Pelayaran Surabaya. International Journal for Educational and Vocational Studies, 1(5), 479-483. https://doi.org/10.29103/ijevs.v1i5.1718

[11] Sri Rahayuningsih1, S. (2016). Disciplinary Character Education At Early Age. IOSR Journal of Research \& Method in Education, 6(5), 42-49. https://doi.org/10.9790/73880605024249

[12] Sugiyono. (2018). Metode Penelitian Kuantitatif, Bandung: Alfabeta.

[13] Sujarwo; Sukmawati;Yahrif, M. (2019). Celebes Education Review: Improving Students' English Learning Outcomes through PQ4R (Preview, Question, Read, Reflect, Recite, Review) Learning Model at the Eighth Grade Students of SMP Tunas Bangsa Makassar. 1, 48-55.

[14] Tsai, K. C. (2012). Bring character education into classroom. European Journal of Educational Research, 1(2), 163-170. https://doi.org/10.12973/eu-jer.1.2.163 